\title{
Scenario, Importance and Prospects of Seed Spices: A Review
}

\author{
Gopal Lal* \\ ICAR-National Research Centre on Seed Spices, India
}

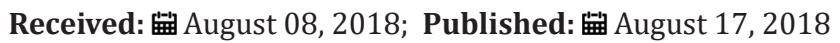

*Corresponding author: Gopal Lal, ICAR-National Research Centre on Seed Spices, Ajmer- 305 206, Rajasthan, India

\section{Introduction}

Arid and semiarid parts of the India are known as Seed Spices Bowl (Rajasthan and Gujarat) and contribute more than $80 \%$ of total seed spices production. Total 109 spices are listed by ISO and 63 spices are grown in India and out of which 20 are being classified as seed spices. Out of 20 seed spices, ICAR-NRCSS working of 10 most important seed spices namely cumin, coriander, fennel, fenugreek, ajwain, anise, caraway, celery, dill and nigella [1]. Seed spices also grown in some other states on considerable areas such as Uttar Pradesh, Madhya Pradesh, Bihar, West Bengal, Orissa, Punjab, Karnataka and Tamil Nadu. Since there is a large scope of seed spices by introducing them in new areas, the higher yields can also be achieved effortlessly by implementing new technologies. Among seed spices, maximum area is under cumin followed by coriander, fennel fenugreek, ajwain, celery, nigella, dill, anise etc. Being seasonal crops, these are grown extensively in rotation with food crops and also as inter/mixed crops under rainfed/irrigated conditions. All these crops mostly grown in rabi season. India is the largest producer, consumer and exporter of seed spices in the world. Seed spices contribute about $51.79 \%$ of total area and 19.06 $\%$ of production of total spices in the country. The area under seed spices is about 1.74 million hectare and production is about 1.45 million tons (DASD, Calicut- 2016-17). India is consistent source of seed spices for importing countries worldwide. There has been ever increasing demand of seed spices and importing countries look at India for quality produce of seed spices.

Seed spices play a significant role in our national economy because of its large domestic consumption and growing demand for export. India is exporting about14 percent of its production annually and full fill nearly 50percent of world demand. India is exporting only 15 percent of its production annually and full fill the 50-60 percent of world demand. The total export of seed spice crops is Rs 3738 crore, out of which cumin alone contributes Rs 2418 crore annually (Spice Board India, 2017-18). Other than India, seed spices are grown in different part of the world covering mainly
Mediterranean region, South Europe and Asia. Morocco, Russia and Bulgaria are the major producing countries for coriander, Turkey, Iran and Egypt for Cumin; Egypt, China, Romania and Russia for fennel; Morocco and Bulgaria for fenugreek; Iran and Egypt for Ajwan; Germany and Hungry for dill; southern France and china for celery; Bulgaria, Cyprus, Germany, and Russia for anise; Pakistan, Sri Lanka and Egypt for Nigella (Table 1).

Table 1: Name of NRCSS mandate crops.

\begin{tabular}{|c|c|c|c|}
\hline $\begin{array}{l}\text { Name of } \\
\text { Crops }\end{array}$ & Scientific Name & Family & $\begin{array}{l}\text { Centre of } \\
\text { origin }\end{array}$ \\
\hline Ajwain & $\begin{array}{l}\text { Trachyspermum } \\
\text { ammi }\end{array}$ & Apiaceae & Egypt and India \\
\hline Aniseed & $\begin{array}{c}\text { Pimpinella anisum } \\
\text { L. }\end{array}$ & Apiaceae & $\begin{array}{c}\text { Eastern } \\
\text { Mediterranean } \\
\text { region }\end{array}$ \\
\hline Caraway & Carum carvi $L$. & Apiaceae & Mediterranean \\
\hline Celery & $\begin{array}{c}\text { Apium graveolens } \\
\text { L. }\end{array}$ & Apiaceae & $\begin{array}{l}\text { Mediterranean } \\
\text { region }\end{array}$ \\
\hline Coriander & $\begin{array}{l}\text { Coriandrum } \\
\text { sativum } L .\end{array}$ & Apiaceae & $\begin{array}{l}\text { Mediterranean } \\
\text { region }\end{array}$ \\
\hline Cumin & $\begin{array}{l}\text { Cuminum } \\
\text { cyminum L. }\end{array}$ & Apiaceae & $\begin{array}{l}\text { Mediterranean } \\
\text { region }\end{array}$ \\
\hline Dill & $\begin{array}{c}\text { Anethum } \\
\text { graveolens L. A. } \\
\text { sowa }\end{array}$ & Apiaceae & $\begin{array}{l}\text { Europe, Africa } \\
\text { and Asia (India) }\end{array}$ \\
\hline Fennel & $\begin{array}{l}\text { Foeniculum } \\
\text { vulgare Mill. }\end{array}$ & Apiaceae & $\begin{array}{c}\text { South } \\
\text { Europe and } \\
\text { Mediterranean } \\
\text { region }\end{array}$ \\
\hline Fenugreek & $\begin{array}{c}\text { Trigonella } \\
\text { foenumgraecumL. } \\
\text { T. carniculata }\end{array}$ & Fabaceae & $\begin{array}{l}\text { South East } \\
\text { Europe and } \\
\text { West Asia }\end{array}$ \\
\hline Nigella & Nigella sativa $L$. & Ranunculaceae & $\begin{array}{c}\text { South and } \\
\text { Southwest Asia }\end{array}$ \\
\hline
\end{tabular}

Source: NRCSS Vision 2050. 


\section{Status of Seed Spice Research in India}

The research work on seed spices since long year back probably start of $20^{\text {th }}$ century. The major breakthrough achieved in that period was identification of cumin blight causal organism i.e. Alternaria burnsii by Uppal [2] and Fusarium oxysporiumf.sp. cumini by Prasad [3] causing Fusarium wilt in cumin. Some conventional work has been reported by Ramanujam [4] found extent of cross pollination in coriander, fennel, ajwain. Further, Patel [5] reported 2-4.5 \% cross pollination in cumin, Ramanujam [4] did some inheritance studies in coriander. To control the stemgall, in coriander Nene [6] used a variety of fungicides. All such work was low in pace and scattered. Systematic research wok started when the Government establishment the All India Coordinated Spices and Cashew Improvement project (AICSCIP) in 1971. The biggest milestone was achieved in1975 when cumin, coriander, fennel and fenugreek were added in the AICSCI project by starting four new seed spices research centres, viz. at Coimbatore (Tamil Nadu), Guntur (Andhra Pradesh), Jagudan (Gujarat) and Jobner (Rajasthan). In 1986, two organizations came into existence, first, All India Coordinated Research Programme on Spicesat Calicut from AICSCIP for research and second, Spice Board of India by merging Cardamom Board (1968) and Spice Export Promotion Council (1966) for promotion ofexport and implementation of various government schemeson spices including seed spices [7].

The landmark achievements were made after the exclusive set up of institutes for R\&D of spices and seed spices. ICAR-Indian Institute of Spices Research Calicut (estb. 1986) and National Research Centre on Seed Spices Ajmer (estb. 2000) have pioneered in developing a number of high yielding varieties and production technologies. AICRP Spices is also conducting location and situation specific research on spices including seed spices at 14 centers in 12 states. During ninth plan period, ICAR established National Research Center on Seed Spices at Ajmer in April 2000 to conduct basic and strategic research exclusively on seed spices crops to further generate technology for enhancing the production and productivity.

\section{Research Achievements}

\section{Germplasm holdings and maintenance}

In the National Agriculture Research System for seed spices includes NRC on Seed Spices and AICRP Spices, the germplasm of seed spices has been evaluated for yield, adaptability and the reaction to diseases and pests, insects-pests, maturity, adaptability, processing attributes and nutritional qualities, maintained scientifically and updated with new accessions. The AICRPS has contributed substantially by enriching germplasm, developing high yielding varieties; technologies for increasing the production and productivity; combating pests and pathogens to reduce crop losses, secondary agriculture etc. The germplasm collection available consists of 1990 accessions in coriander, 499 in cumin, 625 in fennel and 989 in fenugreek. Efforts to update the existing germplasm through the addition of indigenous and exotic collection need to be intensified [8]. There is also a strong need to research for new genes in land races and wild type to develop stress tolerant varieties. The exploration and conservation of germplasm is the prime objective of crop improvement. The total number of germplasms maintained by following center in India (NRCSS, IISR, SKN, Jobner, SDAU Jagudan, TNAU Coimbtore, HAU, Hisar, NDAUT Faizabad etc.) other than NBPGR, New Delhi. The exotic materials have been obtained through the NBPGR (Table 2).

Table 2: Total germplasm assemblage at NRC on Seed Spices, Ajmer, Rajasthan.

\begin{tabular}{|c|c|c|c|c|c|}
\hline \multirow{2}{*}{ NAGS Holding } & \multicolumn{4}{|c|}{ NRCSS Collection } & \multirow{2}{*}{ NAGS Holding } \\
\hline & Indigenous & Exotic & Lost & Present available & \\
\hline Cumin & 100 & 7 & - & 107 & 247 \\
\hline Coriander & 169 & 3 & 27 & 145 & 518 \\
\hline Fenugreek & 82 & 59 & 6 & 135 & 733 \\
\hline Fennel & 118 & 3 & 75 & 46 & 297 \\
\hline Ajwain & 99 & 1 & 9 & 91 & 100 \\
\hline Dill & 106 & 5 & 3 & 108 & 111 \\
\hline Nigella & 21 & 3 & - & 24 & 24 \\
\hline Celery & 36 & - & - & 36 & 36 \\
\hline Anise & 18 & - & - & 18 & 18 \\
\hline Caraway & 8 & 2 & 8 & 2 & 10 \\
\hline Total & 759 & 83 & 128 & 714 & 2094 \\
\hline
\end{tabular}




\section{Development of improved varieties}

(Table 3).

Table 3: Improved varieties of seed spices.

\begin{tabular}{|c|c|c|}
\hline S.No. & Crop & Variety \\
\hline 1 & Cumin & $\mathrm{RZ}-19, \mathrm{RZ}-209, \mathrm{RZ}-223, \mathrm{RZ}-345, \mathrm{GC}-1, \mathrm{GC}-2, \mathrm{GC}-3, \mathrm{GC}-4$ \\
\hline 2 & Coriander & $\begin{array}{c}\text { Ajmer Coriander -1 (ACr 1), Ajmer Coriander - } 2 \text { (ACr- 2), RCr - 41, RCr - 20, RCr - 435, RCr - 436, RCr - 684, } \\
\text { RCr - 446, RCr-728, GCr - 1, GCr - 2, CO- 1, CO- 2, CO- 3, CS- 287, RajendraSwathi, Rajendra Sonia, Sadhna, } \\
\text { Swathi (CS - 6), Sindhu, GCr - 1, GCr - 2, CO- } 1\end{array}$ \\
\hline 3 & Fennel & $\begin{array}{c}\text { Ajmer Fennel-1 (AF - 1), Ajmer Fennel-2 (AF-2), RF - 101, RF - 125, RF - 143, RF-205, PF - 35, GF - } 1 \text { (Gujarat } \\
\text { Fennel - 1), GF - 2, GF - 11, Guj. F.-12, Co - 1, Hisar Swarup }\end{array}$ \\
\hline 4 & Fenugreek & $\begin{array}{c}\text { Ajmer Fenugreek 1, Ajmer fenugreek 2, Ajmer Fenugreek 3, Ajmer Fenugreek 4, Ajmer Fenugreek 5, RMt - 1, } \\
\text { RMt - 143, RMt - 305, RMt-361, GM - 1, CO - 1, RajandraKranti, Andhra Pradesh, Lam Selection-1, APHU } \\
\text { Methi-1, Hisar Sonali, Hisar Suvarna, Hisar Mukta, Hisar Madhavi (HM - 350), HM-219, Pant Ragini, Pusa Early } \\
\text { Bunching, Pusa Kasuri }\end{array}$ \\
\hline 5 & Dill (Sowa) & Ajmer Dill 1 (AD-1), Ajmer Dill 2 (AD-2), GD-1, GD-2, RSP-11 \\
\hline 6 & Ajwain & $\begin{array}{c}\text { Ajmer Ajwain } 1 \text { (AA-1), Ajmer Ajwain } 2 \text { (AA-2), Ajmer Ajwain -93 (AA-93), Pratap Ajwain 1, GA - 1, Lam } \\
\text { Selelction-1, Lam Selection-2, Pant Ruchika, RPA-68, }\end{array}$ \\
\hline 7 & Nigella & $\begin{array}{c}\text { Ajmer Nigella } 1 \text { (AN - 1), Ajmer Nigella } 20 \text { (AN-20), Azad Kalaungi (1998), Pant Krishna (2001), } \\
\text { RajendraShyama, Rajendra Mani }\end{array}$ \\
\hline 8 & Anise & Ajmer Anise 1 (AAni - 1) \\
\hline 9 & Celery & Ajmer Celery-1, RRL-85-1, \\
\hline
\end{tabular}

Source: www.seednet.gov.in.

\section{Quality seed production of seed spices}

Seed replacement rate in seed spices is very low $(15 \%)$ which is a major challenge for enhancing production and productivity of seed spices. Providing good quality seeds is one of the most important and easiest means to accelerate the productivity of seed spices in the country. Although the importance of seed was recognized in ancient agriculture, the need for organized seed production was identified only at the beginning of $20^{\text {th }}$ century when Royal commission of Agriculture (1925) recommended spread of improved varieties and seed distribution. Importance of quality seed includes seed is a vital input in crop production, it is the cheapest input in crop production and key to agriculture progress, crop status largely depends on the seed materials used for sowing, response of other inputs in crop production depends on seed material used, the seed required for raising crop is quite small and its cost is so less compared to other inputs, this emphasis the need for increasing the areas under quality seed production and it is estimated that good quality seeds to improved varieties can contribute about $20-25 \%$ increase in yield.

\section{Production Technology of Seed Spices}

The agro-techniques are highly site specific and vary for different crops. Suitable package of practices including, efficient water, optimum sowing time, seed rate, nursery management, transplanting, spacing, intercultural practices, weed management, cropping system, intercropping and organic farming practices has been standardized for different seed spices crops for realizing the optimum potential of improved varieties in the different agro-climatic conditions. The production technology for off season cultivation has also been worked out for leafy coriander and fenugreek production. In order to boost up production it is important to popularize improved and innovative production technologies for adoption by the farmers. In coriander, plastic covered walk-in-tunnel and shade net covered walk-in-tunnel with low pressure drip system was found highly suitable for off-season cultivation for green leaves. Raised bed technology with drip fertigation and plastic mulching has been found effective for fennel, dill, celery and ajwain. The production potential of seed spices is much larger than that has been achieved so far. In the endeavor to meet the increasing demand of seed spices crops it is now essential to work out complete package of practices varying across seasons, zones and production systems.

Seed spices are basically low nutrient and water requiring crops and seed spices cultivation is confined to the areas where limited water is available for irrigation. Irrigation efficiency is only to the tune of $30-35 \%$, therefore only means to provide the water is effective management and enhancing the water use efficiency to the level of $80 \%$ which is possible with the use of micro irrigation. Lots of initiatives have been taken to apply water in such a manner which can provide maximum output. When, where and how water should be applied has been worked out. Precise irrigation management practices have been developed for seed spices at NRCSS. Normally, all these crops are grown in flat bed, practice of raised bed sowing may be very effective in saving irrigation water as well as maintaining favorable aerobic condition in the root zone throughout the growing season of the crop resulting in better yields. 
Among various methods tried drip irrigation has proved successful in exhibiting high water productivity by saving irrigation water from $25-60 \%$ along with $10-60 \%$ increase in yield as compared to conventional method of irrigation.

Different cropping system has been helpful for crop diversification, efficient utilization of resources and making intensive use of inputs for sustainable income to marginal farmers. The diverse favorable agro-climatic conditions of the country provide opportunity to cultivate variety of horticultural crops such as fruits, vegetables including root and tuber crops, flowers, plantation and spices crops and medicinal and aromatic crops. These crops provide additional income to farmers. Intercropping of fennel or with knolkhol in 1:2 ratio followed by fennel/ dill with cabbage in 1:1 intercropping ratio is very effective for realizing higher yield and benefit. Cluster bean- cumin- summer moong followed by pearl millet- cumin- summer moong cropping sequence is very effective cropping sequence for cumin growing farmers. Intercropping of seed spices in arid fruit orchards has also been assessed and found economical.

However, most of the seed spices are low nutrient requiring crops but fertilizers alone account for $20-30 \%$ of the total cost of production in spices crops. Fertilizer efficiency studies using isotope labelled fertilizers have shown nutrient derived from fertilizer (NDFF) values of 0.5 to $30 \%$. Monitoring soil health and leaf analysis will be useful to ensure a balanced nutrient management and safeguard against hidden hunger. The phosphate rich organic manure (PROM); a value-added product by co-composting different organic wastes with high grade rich phosphate in fine size can be useful in many spices crops and is effective alternative to costly chemical fertilizers. Foliar nutrition method for some of the spices crops has been worked out but there is need to cover more seed spices for high nutrient use efficiency. Besides, use of liquid form of fertilizers through fertigation appears to be promising for deeper application with sizeable input saving. The use of bio-fertilizers, VAM fungi, biological nitrogen fixers and other beneficial microbial agents also need to be optimally used to attain an efficient management.

\section{Protection Technology}

\section{Major insect pests of seed spices}

a) Biological control: Seed spices crops attacked large number of predators and parasitoides due presence of its specific aroma, nectar and pollen on these crops (Table 4). The population of parasitoides found increased with the increase of temperature in Rajasthan and Gujarat condition. The parasites Aphaleeinuskurdijmovi occurs regularly, reaches to its maximum (98 percent) which was observed during November-December. On artificial release, the parasitism increases gradually and reaches up to a maximum in 30 days [9]. The noctuids moth larvae Spodoptera and Helicoverpa attracted large number of parasitoides in field conditions. The common parasitoides are Sturamiainconspicuoides, Actiamonticola, Euplectrusgopimohani. For managing noctuids moth larvae at field conditions 4-6 inaculative releases egg parasitoids 150,000 like Trichogramma Chilonus. T. Brasielensis @150000 parasitoides/ha or starting at first appearance of the moths at 1-15 days interval is found useful., release of larval parasitoids such as Chilonusblackburnii, Braconbrevicornis, Telenoumsheliothinae, Carceliaillota, Coteriakazat or Campoletiscloridae, take care of the already hatched larvae. Coccienellied consist of major predator found feeding on various sucking pests of seed spices. Major coccienellid found predating on seed spices crops are, Coccinella septumpunctata L. Bromoidessuturalis F. Menoochilussesxmacalatus and Adoniasp. Predatory bird myna (Acridotherestristis) was also found feeding on the aphid the other common predators of aphids are Chrysoperlacarnea, Episyrphusbalteatus and Ischiodonscutellaris $[10,11]$.

Table 4: Insect Pests complex of Seed Spices.

\begin{tabular}{|c|c|c|}
\hline Pests Complex & Crop Stages & Common insect pests \\
\hline Soil Insects & $\begin{array}{l}\text { Seed germination to } \\
\text { vegetative growth }\end{array}$ & $\begin{array}{c}\text { Termite, White grubs and } \\
\text { cut worm }\end{array}$ \\
\hline Leaf minors & $\begin{array}{l}\text { Early vegetative } \\
\text { growth }\end{array}$ & Leaf minor \\
\hline Sucking pests & $\begin{array}{l}\text { Vegetative stage to } \\
\text { fruit maturity stage }\end{array}$ & $\begin{array}{l}\text { Aphids, White fly, mite, } \\
\text { Jassids, Thrips, Hoppers, } \\
\text { Seed bug etc. }\end{array}$ \\
\hline Seed/Fruit borer & $\begin{array}{l}\text { Seed development } \\
\text { stage to seed } \\
\text { harvesting stage }\end{array}$ & Seed wasp \\
\hline Defoliators & $\begin{array}{c}\text { Vegetative stage to } \\
\text { seed maturity stages }\end{array}$ & $\begin{array}{c}\text { Helicoverpaarmigera and } \\
\text { Spodopteralitura }\end{array}$ \\
\hline Storage pests & Al storage & $\begin{array}{l}\text { Cigarette beetle and Drug } \\
\text { store beetle }\end{array}$ \\
\hline
\end{tabular}

b) Botanicals: Application of neem based commercial formulation like Neemarin at $1 \%$ and seed extract of neem (Azadirachata indica), karanj (Pongamiasp.), buken (Meliasp.) and pride of India (Lagerstroemia indica) reduce the aphid's population by 50 per cent within 7 days of application (Singh, 2007). Gupta and Rai, 2004 observed 80 per cent reduction of aphid H.coriandri population on coriander crop through spraying of $1.0 \%$ neem oil and achieve highest grain yield 983 $\mathrm{kg} / \mathrm{h}$.In cumin crop aphid M. Persicae population was reduced more than $50 \%$ for 15 days by application Neem Seed Kernal Extract(NSKE) at 5\%. Applications of neem oils and karanj oils successfully controlled early instars larvae of H. armigera and S. litura [12].

c) Chemical control: In cumin crop spraying of phosphomidon-0.03\%, monocrotophos $-0.03 \%$ at 2-week intervals after first appearance of aphids give effective protection. The seed yield o treated plot was $4.7 \mathrm{q} /$ ha in compared to $3.0 \mathrm{qt} / \mathrm{ha}$ on untreated plot [13]. Sharma et al. 
2007 found two application of dimethoat $0.03 \%$, thiomethoxam $0.025 \%$, Imidachlorprid $0.005 \%$ and acephate $0.037 \%$ reduce more than $90 \%$ of aphid (Myzuspersicae) in cumin in 3 days of treatment and give $40 \%$ more yield in comparison to untreated plot. Patel et al 2007 observed application of thiomethoxam @ $12.5 \mathrm{~g}$ ai /ha give significant control of Aphis gossipy in cumin, and there was no significant difference observed in application of double dose of thiomethoxamie, @ 25g ai/Ha. The yield was also at par in both the treatments. Two spray of carbosulfan 25 EC at $1250 \mathrm{ml}$./ha. was found an optimum dose for effectively control of sucking pest population in cumin especially aphids and white fly. Corbosulfan did not showed any adverse effect on natural enemy population and also leave no phytotoxic effect on plant [14]. Uses of aldicarb side dressing at $1.0 \mathrm{~kg} /$ ha, corbofuran $3 \mathrm{G}$ at $0.5 \mathrm{~kg}$ ai $/$ ha., phorate $10 \mathrm{G}$ at $1.0 \mathrm{~kg} / \mathrm{ha}$., endosulfan, $0.03 \%$, phosphomidon $0.03 \%$, monocrotophos $0.03 \%$ effectively reduce the aphid population on coriander crop and increased yield $[15,16]$. Thrips (Thripstabaci and Scirtothrips dorsalis) and mite on coriander was controlled by use of monocrotophos at $0.5 \mathrm{~kg} / \mathrm{ha}$ and chlorpyriphos at $0.05-1.0 \%$, Rao et. al., 1983. Insecticidal control of aphid Hyadaphiscoriandri on fennel was achieved by application of foliar spray of $0.05 \%$ quinolphos, $0.07 \%$ endosulfan, $0.009 \%$ cypermethrin, $0.05 \%$ dichlorvos, $0.025 \%$ methyl parathion $0.03 \%$ phosphomidon, $0.03 \%$ dimethoate and $0.01 \%$ fluvalinate [17]. At flowering stage application of methyl parathion $0.025 \%$ and endosulfan $0.07 \%$ minimizes infestation of seed midge in fennel crop during storage [17]. Two application of metasystox at $0.05 \%$ significntely reduce thrips population on fennel crop [18]. Application of dimethoate at $0.045 \%$ and metasystox at $0.03 \%$ gave maximum aphid control in fenugreek crop and give highest yield (6.87 and 6.27 qt./ha) [19]. Effective management of Spodopterlitura and Helicoverpaarmigera on cumin, coriander, fennel fenugreek and nigella were achieved by application of $0.05 \%$ monocrotophos fallowed by $0.2 \%$ aldicarb after 10 days, fenvalerate $50 \mathrm{~g}$ ai/ha. orendosulfan at $700 \mathrm{~g}$ ai/ha (Table 5).

Table 5: Important diseases of seed spices.

\begin{tabular}{|c|c|}
\hline Seed Spice & Disease \\
\hline Cumin & Wilt, Blight, Powdery mildew \\
\hline Coriander & Stem gall, Powdery mildew, Wilt, Blight disease \\
\hline Fennel & Leaf blight, Wilt disease, Powdery mildew, Root rot \\
\hline Fenugreek & $\begin{array}{c}\text { Dumping off, Leaf spot, Leaf blight, Powdery } \\
\text { mildew, Downey mildew }\end{array}$ \\
\hline Nigella/Kalongi & Root rot, Powdery mildew \\
\hline Ajwain & Alternaria blight, Collar rot. Powdery mildew \\
\hline Sowa (Dill) & Powdery mildew, Dill blight \\
\hline Celery & $\begin{array}{c}\text { Stem rot, Bacterial leaf spot, Early bligh, tSeptoria } \\
\text { spot }\end{array}$ \\
\hline Anise & Leaf blight \\
\hline
\end{tabular}

\section{Major disease of seed spices}

Control: The disease infestation in seed spices lower the production and productivity. Hence management of disease one of the important practices which can enhance the productivity of seed spices. Diseases like wilt, blight and powdery mildew in cumin; wilt, powdery mildew and stem gall in coriander; blight and gummosis in fennel, and powdery mildew, downy mildew and mycoplasma-like organisms (MLOs) in fenugreek frequently attack these crops causing heavy loss of yield and deteriorate the quality of the produce. Though the package of practices for the control/ management of each of these diseases have been formulated but still diseases like wilt (cumin and coriander), root rot (fenugreek) and gummosis (fennel) are difficult to be controlled completely. Concerted efforts are needed to evolve appropriate technology for their effective control or varieties which can tolerate or resist this disease. Methodology developed and recommended by NRCSS, Ajmer for control of important diseases are as under.

a) Application of mustard residue (2.5 t/ha) + mustard cake $(0.5 \mathrm{t} / \mathrm{ha})+$ neem cake $(0.5 \mathrm{t} / \mathrm{ha})$ as soil amendment with one irrigation during hot summer.

b) Application of T. viride or A. versicolar as seed treatment @10g/kg seed and soil application @ $2.5 \mathrm{~kg} / \mathrm{ha}$ mixed with 50 $\mathrm{kg}$ of FYM at the time of sowing.

c) ST with Trichoderma, SA with cator cake and FS with chlorothalonil followed by two sprays of difenoconazole and azoxystrobin was found most effective for the management of Alternaria blight of cumin.

d) Soil Solarization in combination with oil cakes has been found highly effective.

e) Two sprays of Neem oil (2\%) at 10 days intervals during flowering in evening hours.

f) Chemical control.

\section{Organic Seed Spice Production Technology}

a) In a study at NRCSS, application of organic Module-1 comprising of soil application of vermin-compost, Trichoderma and neem cake as well as seed treatment of Azotobacter, PSB and Trichoderma with the foliar spray of garlic extract and neem oil is better for realizing higher, growth and yield parameters as wells as yield and net return.

b) Application of 7.5t/ha sheep manure followed by 4.0t/ha vermi-compost with bio-fertilizer Azotobactor@250g/ha seed in coriander is better for realizing higher yield in cumin and coriander.

c) Application of $75 \% \mathrm{~N} \& \mathrm{P}$ through vermin-compost andenriched vermi compost with seed inoculation by 
Azotobactor and PSB is economical organic nutrient management strategy in coriander and cumin.

d) Seed treatment along with soil application of Trichodermaviridae @2.5kg/ha and soil application of neem cake@150kg/ha and foliar spray of karanj oil for is an integrated approach for disease management in coriander under organic coriander production.

e) Insecticidal soap developed by NRCSS (neem oil based$1 \%)$

f) In coriander, application of PSB + Azotobactor along with FYM.

\section{g) In fenugreek Rhizobium treatment along with FYM}

\section{Postharvest management and processing of seed spices}

The postharvest handling activities start after the harvesting of crop, first with drying of freshly harvested crop, threshing, seed drying, cleaning, grading, packing and transportation of whole seed to market, processing plant or storage place. On farm processing is an important aspect to prevent deterioration of the produce and maintain the quality [20]. Improvements in hygiene, packing and storage facilities help in keeping quality of spice flavours and reduce chances for afla-toxin and salmonella contamination of seed spices. Many products have been developed by NRCSS in seed spices such as essential oil, oleoresins, cryogrind powder of seed spices, coriander, fennel, dill squashes, RTS, biscuits etc.

\section{Technologies Dissemination}

Only $40 \%$ farmer households in India have access to various sources of information for modern technology for farming [20]. The popular information sources among farmers have been reported to be fellow progressive farmers and input dealers, followed by mass media. The public extension system and extension workers have been found to be accessed by only $5.7 \%$ households. Only $4.8 \%$ of the small farmers have access to public extension workers as compared to $12.4 \%$ of large farmers. Public-sponsored other extension methods, like training programs, study tours and so on, were found to have least influence on the adoption of modern farm technologies. The ratio of extension staff to farmers varies widely across the country from 1:300 in Kerala to 1:2000 in Rajasthan [21]. Looking the scarcity of transfer of technology NRCSS used to disseminate the developed technology through collaboration with different KVKs, farmers fair, training programme, fields days, Front Line Demonstration (FLDs) etc [22,23].

\section{Major Challenges in Seed Spices}

Certainly, there is lot of scope and opportunities in seed spice but many emerging challenges which are needing to tackle to sustain the production and increase the farmer's income. These challenges includes; wilt, blight and yellowing disease in cumin, stem gall problem in coriander, dwarf varieties with tolerance to Ramularia blight and gummosis in fennel, seed replacement rate (SRR) of seed spices is very needed to be increased, standardization of minimum seed standards in seed spices, priming and pelleting of the seeds of seed spice to hasten the germination [24], Focused work is needed to develop GAP standards for organic and nonorganic seed spice cultivation both for domestic and international need, PoP's for better resource management, development of climate resilient varieties, GAP's as per domestic and international market, pollination management in seed spices, promoting production of organic seed spices, mechanization and precision farming, pesticide residue management, forecasting models for IDM/IPM, post-harvest handling and processing for value addition etc. The seed spices improvements for harnessing genetic potential through collection and characterization of germplasm to enhance the variability and ultimately developments of superior varieties. Recombination breeding should be promoted to enhance the yield and quality in seed spices [24]. There is strong need for development of molecular markers database and mapping population in seed spices for tagging of candidate's genes.

\section{Prospects of Seed Spices}

Seed spices are used for imparting flavour and taste to food and also have huge medicinal properties for health benefits to treat multiple diseases. Though seed spices have been using in Unani and Ayurvedic medicines, but extensive work should be done to know the potentiality of seed spices to cure the various human and animal diseases. Seed spices are an important horticultural crop and these areas mainly concentrated in arid and semi-arid parts of India. Seed spices can be accommodated in other crops in different cropping and/or farming system. The fenugreek can be grown as a fodder crop which is rich in protein. The straw from different spices can be used as a feed for the animal by blending it in different ratio. Seasonal vegetables and flowers can be rotated intercrop with seed spices (Lal and Verma, 2018). Increasing health consciousness among the spice user especially the European and American community leads to the growing demand for organic crop products including spices. It has led to the development of international trade for organic spices. India is traditionally cultivating spices organically. Though there is need to increase the area under organic cultivation of seed spices. Exporters specializing in organic production have been successful in achieving the international standards prescribed for spices (Malhotra, 2010). Seed spices mostly cultivated in arid and semi-arid area of the country and these crops have ample scope for expansion of areas under seed spices in different agro climatic Zones and Sub Zones as well as new areas in the country particularly Northern Estates, Andhra Pradesh, Karnataka, Bihar, Chhattisgarh and Jharkhand. Mechanization and value chain management in seed spices to ensure the high quality and better price of the produce. 
To realize the export and domestic demand of seed spices, there is need to enhance the quality through value chain management. Value addition in seed spices are very low majority of export is in the form of whole spices from India. So, work should be focused on valued addition in seed spices by various means. India enjoys the status of largest producer of seed spices in the world but the productivity in the country is very low and it is bellow potential of the crop varieties. There is a considerable gap between achievable and realized productivity, hitherto the national average yield has not registered the significant rise and need to be work on it. India is today in the enviable position as one of the worlds 's largest producer of seed spices and is a major player in the global market. India has the better potential of increasing the production of seed spices crops and future prospects of their export are many. The seed spices can be grown successfully under saline/alkaline water, acid soils, eroded lands, lower fertile soils, limited soil moisture conditions and metal polluted soil. These seed spice not only thrive well under these odd situations but also improve them by following means. Some seed spices have potential for hyper accumulation of salt resultant helps in reclaiming saline sodic soil such as fennel and coriander. Thereby reduction in soil $\mathrm{pH}$ and ESP and increase in exchangeable calcium takes place in soil. Seed spices crops could be successfully grown on heavy metal polluted soils and under atmospheric pollution as substitutes for some other edible crops and removes the appreciable amount of heavy metals by hyper accumulation.

\section{Summary}

India has attained self-sufficiency and stability in food production. These helped India to become food security to the population and providing balanced diet. India has always been known as land of spices. The term spices refer to such natural plants or vegetable products or mixtures in whole or ground form and as used for imparting flavor, aroma and piquancy to and for seasoning of foods. India has a magnificent past, pleasant present and a bright future with respect to production and export of spices. Seed spices are extensively grown in arid and semi-arid tracts of Rajasthan and Gujarat where climatic condition is very harsh, and these crops provide livelihood to large section of the population in the dry areas. In recent years, organic farming has gained considerable importance. The spices produced from this type of farming are without any harmful ingredients. More than 100 varieties have been developed in different seed spices and seed are available for cultivation. Many packages of practices for seed spice crops have been developed. Management module for insect pests and diseases already been developed. Many products have been developed and many need to develop to promote postharvest technology in seed spices such as essential oil, oleoresins, cryogrind powder, squashes, RTS, biscuits, dill parag etc. Besides the enormous scope, there is certain emerging challenges to which, there are urgent need to answer these problems to double the farmer's income. Such challenges include, wilt and blight disease in cumin, stem gall problem in coriander, dwarf varieties with tolerance to ramularia blight and gummosis in fennel, the priorities research in years to come have been identified as crop diversification with seed spices, breeding for resistance to biotic and abiotic stresses, breeding for quality and value added products, value chain management, use of biotechnology, pesticides residue.

\section{References}

1. NRCSS Annual Report, 2015-16 NRCSS Vision (2050) NRCSS, Ajmer, India.

2. Uppal BN, Patel MK, Kamat MN (1938) Alternaria blight of cumin. Indian J Agric Sci 8: 49-62.

3. Prasad N, Patel PN (1963) Fusarium wilt of cumin (Cuminum cyminum L.) in Gujarat State, India. Plant Disease Report 47: 528-531.

4. Ramanujam S, Tewari VP (1966) Inheritance of plant height in coriander. Indian Journal of Genetics and Plant Breeding 26(2): 217-219.

5. Patel RM, Patel RA, Patel RM (1966) Extent of natural cross-pollination in cumin. Indian Journal of Genetics and Plant Breeding 26(2): 220-222.

6. Nene YL, Siddiqui IA, Kharbanda PD (1966) Control of stem gall of coriander by fungicides. Mycopathology and Applied Mycology 29(1) $142-144$.

7. Singh B, Solanki RK (2015) Status of seed spices research and development in India. Indian Journal of Agricultural Science 85(2): 151156.

8. Verma AK, Choudhary S, Meena RS, Lal G, Sharma M (2018) Improvement of seed spices. In: Phytochemistry of Fruits and Vegetables (Peter, K.V. Editor). Brillion Publishing, New Delhi, India, pp. 287-314.

9. Kumaresan D, Regupathy A, Baskaran P (1988) Pest of Seed Spices. Rajalakshmi Publication. pp. 1-241.

10. Singh MP (2007) Integrated pest management (IPM) in seed spice. Paper presented in National Seminar on Production, Development, Quality and Export of seed spices. NRC Seed Spices, Tabiji, Ajmer, Rajasthan, India. pp. 139-148.

11. Mittal VP, Butani PG (1994) Pests of Seed Spices. In Advances in Horticulture Volume-10Plantation and Spice Crop part-2. (Chadha KL, Rothinan P, eds.). Malhotra publishing House, New Delhi, India. pp. 825855 .

12. Sharma KL, Kumawat KC, Yadav SR (2007) Relative bio efficacy of different insecticide against aphids Myzuspersicae Sulzer on cumin. Paper presented in National Seminar on Production, Development, Quality and Export of seed spices. NRC Seed Spices, Tabiji, Ajmer Rajasthan, India. pp - 336-341.

13. Gupta BM, Yadav CPS (1986) Susceptibility of released and elite cumin germplasm to aphid. Indian Cocoa, Arecanut and Spices Journal 9(3): 174-76

14. Ameta OP, Gupta HCL (2007) Studies on bioefficacy, biosafety and dissipation of carbosulfan $25 \mathrm{EC}$ in cumin, for the management of sucking insect pests. Paper presented in National Seminar on Production, Development, Quality and Export of seed spices. NRC Seed Spices, Tabiji, Ajmer, Rajasthan, India. pp. 357-364.

15. Jain PC, Yadava CPS (1989) Incidence of insect pests and their control and coriander. India Cocoa Arecanut and spice Journal. 13: 61-62.

16. Meena PC, Sharma JK, Noor (2003) A Effect of a biotic factors on the occurrence of aphid, Hyadaphiscoriandri (Das) and Coccinella predator on coriander varieties. Annal of Agri Bio Research 7: 181-186. 
17. Mittal VP, Butani PG (1995) Chemical control of seed midge (Systole albipennis walker) infesting stored fennel. Gujarat Agriculture University Research Journal 20: 189-192.

18. Sagar P (1987) Efficacy of some insecticide against thrips, Thrips flavus Schrank, a pest of fennel in the Punjab. International Pest control 29(6): 130-133.

19. Kumawat KC, Singh SP (2001) Bio efficacy of insecticide against aphids, Acyrthosiphonpisum on fenugreek. Annals of Plant Protection Science 8: 167-171.

20. Adhiguru P, Birthal PS, Kumara GB (2009) Strengthening pluralistic agricultural information delivery systems in India. Agricultural Economics Research Review 22: 71-79.
21. Raabe K (2008) Reforming the agricultural extension system in India. What do we know about what works where and why? IFPRI Discussion Paper, pp. 775.

22. Lal G, Verma AK (2018) Seed species for diversified agriculture to enhance farmers income. In: Shod Chintan- Intensification and Diversification in Agriculture for Livelihood and Rural Development (Editors: H.P. Singh, R.C. Srivastava, Dhiraj Sharma and Babita Singh), ASM Foundation, New Delhi, India. 10: 214-219.

23. Malhotra SK (2010) Organic Seed spices production. In: Singh, H.P. and Thomas, J. (Eds.). Organic production practices in Horticulture. Westville Publ, New Delhi, India, pp. 83-119.

24. Patel PN, Prasad N, Mathur RL, Mathur BL (1957) Fusarium wilt of cumin. Curr Sci 26: 181-182.

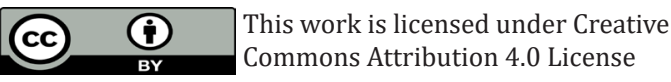

To Submit Your Article Click Here:

Submit Article

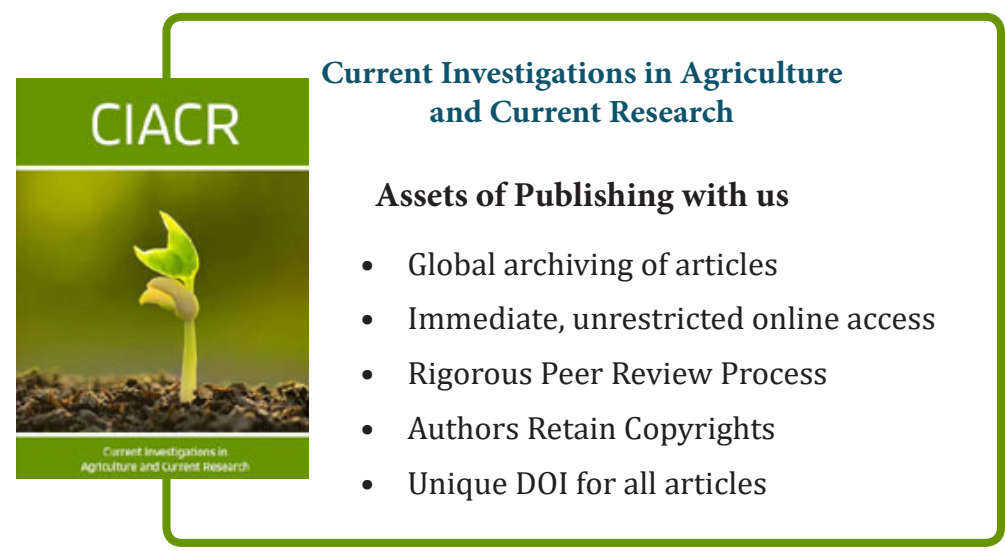

